This is the accepted manuscript of the article, which has been published in Politics \& Policy. https://doi.org/10.1111/polp.12331

\title{
The spread and domestication of the term "austerity": evidence from the Portuguese and Spanish parliaments
}

\author{
Laia Pi Ferrer ${ }^{a *}$, Pertti Alasuutari ${ }^{\text {a }}$ \\ ${ }^{a}$ Faculty of Social Sciences, Tampere University, Finland
}

*Laia Pi Ferrer: Tampere University, Faculty of Social Sciences, Kalevantie 4, FI-33014, 33100 Tampere, Finland.

Phone: +358 503187496

e-mail: laia.piferrer@tuni.fi

Pertti Alasuutari: Tampere University, Faculty of Social Sciences, Kalevantie 4, FI-33014, 33100, Tampere, Finland.

Phone : +358 504211053

e-mail: pertti.alasuutari@tuni.fi

*corresponding author: Laia Pi Ferrer (laia.piferrer@tuni.fi)

ORCID:

Laia Pi Ferrer https://orcid.org/0000-0001-8655-591X

Pertti Alasuutari http://orcid.org/0000-0003-4111-9641

This is an Accepted Manuscript of an article published by Wiley in Politics \& Policy on 18 November 2019, available online:

https://onlinelibrary.wiley.com/doi/full/10.1111/polp.12331

The full reference of the Version of Record (publisher's version): Pi Ferrer, L., Alasuutari, P. (2019). The spread and domestication of the term "austerity": evidence from the Portuguese and Spanish parliaments. Politics \& Policy, doi.org/10.1111/polp.12331 


\section{Acknowledgements:}

The authors wish to acknowledge Leena Tervonen-Gonçalves and members of the Tampere Research Group for Cultural and Political Sociology for comments on earlier versions. Thanks also to the anonymous reviewers and the editor-in-chief of Politics \& Policy for sharing insightful comments. This work was made possible by financial support from the Academy of Finland (grant numbers 276076 and 294183), whose assistance is appreciated. 


\title{
The Spread and Domestication of the Term "Austerity": Evidence from the Portuguese and Spanish Parliaments
}

\begin{abstract}
This article explores what happens when the term "austerity" becomes a global catchword. Specifically, we study how this term has been used in national policy making in the Portuguese and Spanish parliaments from the 1970s until recently. We show that although Portugal and Spain were in a somewhat different situation regarding the 2008 economic crisis, the increased popularity of the term austerity occurred practically simultaneously in the Portuguese and Spanish parliaments. This suggests that the term's popularity in political debates is not solely determined by a nation's political or fiscal situation. Rather, our contention is that employing the term austerity to discuss government policies became a global fashion after the fiscal crisis of 2008. The study also shows why austerity became an increasingly popular concept: the term changed from being mainly used in fiscal policy to being commonly used in other policy areas too.
\end{abstract}

Keywords: Austerity, Economic Crisis, Parliamentary Debates, Europe, Spread of Ideas, Discursive Politics, Discourse Analysis, Political Concepts, Valence, Floating Signifiers, Domestication, Catchword, Portugal, Spain.

\section{Introduction}

Austerity has become a fashionable term in recent years. In fact, the Merriam Webster dictionary named "austerity" its "Word of the Year" in 2010 after an increase of over 250,000 searches for this term in its online dictionary. The term became an international trend for naming government policies after 2008, mainly because many international organizations started proposing, recommending, and even pressuring states to adopt austerity policies after the bailouts as a remedy to economic imbalance, (see e.g., Kriesi 2002; Panitch and Gindin 2009; Potts and Montero 2010). As such, different nation-states, at the same time, started addressing economic problems and public debts by following this international recommendation (see e.g., Petry 2013; Salomon 2015; Walter 2016). In the meantime, many social movements and political parties, especially in Europe, challenged the wisdom of "austerity" (see e.g., Della Porta and Mattoni 2014). 
In this article we investigate the ways in which the term and concept of "austerity" became so popular in political discussions. This is an important topic from the perspective of the global travel of ideas: new concepts emerge, spread, and become used in different countries and spheres of life. It is crucial to study the process by which a term turns into a catchword that becomes used in ever-new contexts, re-framing, and reorganizing political discourses and actual policies. To address this issue this article traces how the term "austerity" (austeridad in Spanish and austeridade in Portuguese) has been used in Portuguese and Spanish parliamentary discussions from the 1970s until recently. We selected these two countries as case examples because, first, the global financial crisis from 2007 onward hit them hard, making plenty of discussion on austerity measures in the national parliaments very likely and a good source for analysis. Second, Portugal and Spain provide an interesting comparative pair in that the timelines of the crises differ in some critical ways. In 2011-14, Portugal experienced an international bailout. Spain was not bailed out, although it received rescue loans from Eurozone funds in 2012. Starting from the assumption that the prevalence and contents of the discourses on austerity reflect a country's economic situation, we could therefore expect to find that the discussions in these countries have different patterns. Nevertheless, as our analysis will show, the timing and discussions on austerity in these countries differ very little. This shows that very similar discourses on austerity spread transnationally without necessarily requiring much specificity as to the political situation of the country. Indeed, an explosion in the use of the term austerity started in the Spanish parliament in 2008 and in the Portuguese parliament in 2009, reaching its peak in the Spanish parliament in 2012 and in the Portuguese parliament in 2013. Our explanation for this increased use is that the concept acquired new meanings and brought new discourses to bear, which is why it spread from fiscal policy to other issue areas.

The rest of the article is organized as follows. After discussing the theoretical framework, the data and methods are introduced in more detail. The empirical analysis is divided into three sections. First, we introduce and describe quantitatively how the term austerity has been used across the time 
span studied. Second, we identify the different ways in which austerity has been used as part of the justifications for national policy making. Third, we explain how it has been used in different policy areas and by different political parties. Finally, we discuss our findings, linking them to the larger theoretical framework.

\section{The Appearance, Diffusion and Domestication of Global Ideas: The Case of "Austerity"}

After the collapse of the Lehman Brothers and the beginning of the global financial crisis, governments across the "developed" world, especially in Europe, introduced austerity policies (McBride 2014). But what is austerity? Although this term was used to describe dry or stark conditions before the Second World War, it was not until the 1950s that it started to acquire economic connotations (Anderson and Minneman 2014). This might refer to different things, such as adopting a debt-reduction package based on tax increases, or adopting spending restraints on social programs (de Rugy 2013). In fact, many scholars suggest different interpretations of what defines austerity (see Blyth 2013a; Lanchester 2013; Bramall 2013; Anstead 2017), which makes it evident that there is no clear consensus on its meanings, definition, and scope (see also Anderson and Minneman 2014).

When discussing and evaluating the possible benefits and drawbacks, there are also many opinions. For example, some authors point out the inappropriateness of austerity as it does not help to re-establish growth and the economy in a general sense (see Guajardo, Leigh, and Pescatori 2014; Theodoropoulou and Watt 2011), causing at the same time alarming social costs (Clarke and New man 2012). Others, however, suggest that austerity can generate growth (see Alesina and Perotti 1997; Alesina et al. 2002). Yet the lack of a general agreement about the meaning of austerity and the variety of ideas on its effects and benefits has not impeded this term from becoming popular and widespread. Clarke and Newman (2012) remark that it seems to be a dominant piece of global wisdom in the political domain. Relatedly, as Fontana and Sawyer (2011) argue, ideas about austerity measures are powerful, as no policy maker around the world seems to be immune to them. 
Authors offer different explanations as to why austerity became dominant and prevalent in public policy. For instance, Dellepiane-Avellaneda (2015) suggests that influential networks of policy experts exert a key role in defining solutions to problems such as economic crises. Helgadóttir (2016) shows that economic models such as the concept of expansionary austerity espoused by a network of economists from Bocconi University, Milan, have shaped responses and actions in the 2008 financial crisis. Others conversely focus on differences in approaches to it. Lallement (2011), for instance, demonstrates that austerity measures and adjustment mechanisms in the labor market have varied from country to country. It has also been suggested that the ideology of the party in government affects the way austerity is approached (Mulas-Granados 2003). For example, Tavares (2004) argues that left-wing governments tend to decrease the budget deficit by increasing taxes, whereas rightwing governments frequently count on spending cuts. Traditionally, it has been suggested that parties from the right are more likely to advocate neoliberal ideas such as austerity, whereas parties representing the left tend to support Keynesian ideas (Boix 2000; Alesina and Rosenthal 1995). However, many scholars point out that austerity obtains predominance in politics even in countries that do not have a right-wing government (Jabko 2013). In addition, Anstead (2017) suggests that the polarization between the pro-austerity right and anti-austerity left is not so neat.

As the literature indicates, austerity has gripped the global political scenario. Therefore, in this study we want to empirically look at the ways in which the term austerity has been used in political discourses and has gained a central position in debates on economic policy. This relates to the wider theoretical discussion on how ideas spread globally and become domesticated nationally. It has been argued that ideas matter in politics (Jacobs 2009; Schmidt 2008) as they influence policy outcomes (Béland and Cox 2016), but discourses also matter for policy changes (Schmidt and Radaelli 2004; Schmidt 2001). Hence, discursive institutionalism is an umbrella concept that helps us to understand and analyze ideas and discursive interactions within an institutional context (Schmidt 2012). Although ideas and discourses are key elements, they cannot be considered independent 
entities (Schmidt 2012). Ideas do not "float freely" (Risse-Kappen 1994) and discourses need to be produced. Put differently, there need to be agents who communicate ideas through discourses (Schmidt 2015). It is through the discursive interactions that agents argue, deliberate, and possibly end up participating in collective action. This is especially important in the political sphere, where policy makers need to coordinate discourses among policy actors to reach agreements on policies. The agreements are not often clear-cut; rather the process of deliberation and argumentation implies a variety of different discourses and ideas. Agents, at the same time, cannot generate isolated discourses and ideas if they want to produce an impact on the policy in question. Policies need to be grouped with similar ideas and discourses into discursive communities to influence and shape policies (Schmidt 2012). As Schmidt (2011) points out, this interactive process in institutional contexts contributes to policy change, which is always continuous and dynamic.

Following Carstensen (2011a, 600), the concept of idea can be defined as a "web of related elements of meaning." However, not all the ideas gain the same importance. An idea can be considered successful when it generates enough critical support to be adopted into policy (Béland and Cox 2016). To become successful, ideas need to have ambiguity or polysemy. In other words, ideas need to mean different things to different people. These qualities generate conflicts and contradictions in their application and understanding, but at the same time they make such ideas more appealing to a greater number of people. Thus, actors try to mold an idea in a way that helps them to build support (Béland and Cox 2016, 431). Similarly, Jenson (2010) claims that highly ambiguous and polysemic ideas are likely to better appeal to coalition builders than strictly defined concepts. It is for this reason that Béland and Cox $(2016,429)$ argue that ambiguous and polysemic ideas can have the capacity to act as "coalition magnets": they can appeal to different individuals and groups and used strategically by policy entrepreneurs. For instance, Hofferberth (2015) shows that the conceptual vagueness and ambiguity of "global governance" have constituted it as a "floating signifier"- that is a deluge of different and multiple meanings and interpretations. Similarly, Jabko (2006) suggests that the 
European Union (EU) has chosen "market" as a key concept for building power at the European level. However, various ideas about the market are used to justify different integration actions: the market is used as a constraint in the financial sector, as a norm in solar energy, and as a space in the regional economic sector. Apart from ambiguity and polysemy, Cox and Béland (2013) advocate valence as another important quality. For them, valence denotes the attractiveness of an idea, which can be either positive or negative in nature, and high or low in intensity. From this perspective, ideas have much more political impact if they are high in valence: if they generate strong reactions in people regardless of their political preferences.

As to how new political ideas emerge, Carstensen $(2015,284)$ stresses that "ideas do not emerge from an absolute origin but instead are created when a set of ideational elements are yoked together by political actors," creating what he calls "ideational novelty." Their meanings are constituted by infinite connections back in time (diachronic) or across other ideas (synchronic). As their meanings are based on their relation to other ideas, and these are never totally fixed (Laclau and Mouffe 1985), ideas may change (Carstensen 2015). Yet, ideas do not change by themselves. Actors need to use and activate them strategically for a political purpose (Béland 2005). Carstensen (2011b) argues that actors are bricoleurs (a term first used by Levi-Strauss 1962) as they recombine elements from the existing repertoires of ideas to create new meanings. Therefore, ideas are in constant flux and come from everywhere (Kingdon 1984). But not all of them survive and prosper; some vanish (Kingdon 1993). In this line of research, it is said that "an idea's time has come" when there is a change, when there are new events on the agenda that open a "window of opportunity" for new ideas to impact upon politics or resolve political issues at a precise moment (Kingdon 2003). Previous research has suggested that ideas are important to explaining new events such as crises (Blyth 2013a; Schmidt 2014). But new events can also reformulate ideas (Anstead 2017). The interest in ideas, however, remains contingent upon their impact and receptivity in a given situation (Kingdon 1984). Impact and receptivity can, of course, be national and transnational (Béland and Cox 2016). 
In ideational theory, scholars also stress that crises give rise to new ideas due to a different and unstable situation, laying foundations for their emergence (Anstead 2017; Baker and Underhill 2015). As Blyth (2013b) observes, ideational change is a consequence of the dynamism needed for rational information updating, learning, and error correction. When there is instability and uncertainty, actors look for new discourses and interpretations to explain the particular circumstances in which they are absorbed, and to find proper solutions to deal with them (Chwieroth 2010). Accordingly, previous studies have suggested that political actors resort to new and alternative ideas and discourses when there is a new political situation in which previous ones do not work, and crises may be examples of this (Carstensen 2011a; Béland 2009).

Research on the global travel of ideas, on the other hand, suggests that "actors in different national states are receptive to the same signals—-such as signs of economic booms and recessionsand respond to them similarly" (Alasuutari 2016, 163). Béland (2009) notes that policy ideas often gain a transnational dimension through the actions and discourses of think tanks, politicians, academics, and international organizations like the International Monetary Fund (IMF) (see e.g., Chwieroth 2007). Accordingly, Simmons, Dobbin and Garrett (2008, 7) point out that national decision making is interdependent; "policy decisions in a given country are systematically conditioned by prior policy choices made in other countries."

Related to the global travel of ideas, the "Stanford School" of world society theory also stresses the importance of international organizations as conduits of ideas or policies. A plethora of studies show that the current situation of a country-i.e., the suitability of a policy to the domestic conditions-does not predict well which countries are the first to enact a model that spreads worldwide. Rather, whether a nation-state enacts a particular worldwide model appears to depend on how well connected the decision makers are to the international organizations that promote it (Shandra 2007; see also Hafner-Burton and Tsutsui 2005; Hafner-Burton, Tsutsui, and Meyer 2008). 
Consequently, governments make reforms that are badly suited to their current situation (Meyer 2004).

Since ideas and catchwords spread globally, it is also important to note the institutional conditions for their adoption and domestication (Alasuutari and Qadir 2014) in different national and organizational contexts. In this respect, Strang and Meyer (1993) emphasize theorization: for ideas to travel transnationally, they have to be developed into abstract models, which means that they are easily transferable. Furthermore, if adopting a term is connected to money or other material interests, it easily spreads among those who could benefit from referring to it. For instance, the term "social cohesion" became increasingly popular from the mid-1980s onward, especially within the European Union, because it depicted a new policy instrument—-the so-called Cohesion Fund — that aimed to even out the differences in wealth among the EU member states (Alasuutari 2016, 130-44). Similarly, the catchphrase "war on terror," coined by the administration of President Bush in 2001, spread far beyond its original meaning to varied contexts and uses; for instance, in Pakistan. That is, actors began to discuss otherwise unrelated events—including women's rights and honor killings— through the lens of the war on terror. The underlying motive for this national domestication of the catchphrase was the general conclusion by most Pakistan politicians, analysts, and even civil society members that the world "owes us," especially financially, for fighting this war (Qadir and Alasuutari 2013).

Existing scholarship thus suggests several hypotheses to be examined in the empirical part of this study. On the basis of the theories that stress the right moment—such as a crisis—as a key condition for an idea to be adopted in a "recipient country" we could expect that the frequency with which domestic politicians evoke the concept of austerity follows a national pattern. On the basis of world society theory, on the other hand, we could assume that, once austerity becomes a worldwide catchword, political actors would start using the concept regardless of the domestic situation. What explains the increased use of the term austerity in national political debates leads to another set of 
questions. Does its conceptual travel mean that austerity is evoked in an increasing number of contexts; or that it re-frames various disputes as its instances?

\section{Data and Methods}

To study in detail how the term austerity has been used in policy making, we analyze parliamentary plenary sessions from two countries: Portugal and Spain. The reason for choosing these two countries is that they are good examples of nation-states that have suffered from the recent economic crisis. Major reforms and cutbacks were made (Andrade and Duarte 2011; Royo 2013), which is why it can be expected that there was plenty of discussion on austerity measures in the national parliaments. Furthermore, these two countries represent a good comparative couple as they share many cultural, historical, and state development ties: the constitution of democracy after the dictatorships was achieved more or less at the same time, as was the case with joining international organizations such as the EU (see e.g., Sardica 2014; Queirós 2009). In addition, they have been grouped as part of the same family of nations (Obinger and Wagschal 2001), which makes the two countries easily comparable. Finally, in terms of practical accuracy, these two countries were chosen because they share the same Latin etymology, meaning, nature, and usage of the term austerity, which makes them comparable regarding language and discourses.

At the same time, they are interesting cases due to some differences: while the Portuguese government received bailout packages for the state from June 2011 until May 2014 by the "Troika" (European Central Bank, European Commission, and the International Monetary Fund), in Spain the bailout was conducted only in the banking sector in 2012 (Afonso, Zartaloudis, and Papadopoulos 2015). Hence Portugal received financial support conditional upon the reforms included in the Memorandum of Understanding (MoU) (Moury and Standring 2017), which forced the government to comply to a series of rigorous obligations (Gorjão 2012). In Spain, there were no such obligations, but structural reforms were requested to purchase sovereign bonds (Moury and Standring 2017). With 
the present study, we aim to ascertain whether and how these different conditions affected the frequency with which austerity was evoked.

The data used consist of all the parliamentary plenary sessions ${ }^{1}$ covering the time span from 1975 to 2017 in Portugal and from 1977 to 2017 in Spain. ${ }^{2}$ All the documents analyzed are public and easy to access through the parliamentary online data archives. ${ }^{3}$ The time span of four decades is certainly long enough to detect discursive changes in the use of a term (see e.g., Tervonen-Gonçalves 2012). Parliamentary debates are particularly appropriate material for this study, as they provide a forum where global ideas are brought up and integrated into the political discourses within a nation. The significance of these public debates is that Members of Parliament (MPs) construct their arguments in ways that persuades the majority of the audience of what they propose to be the right and reasonable way to proceed in a given situation (Alasuutari 2016).

The analysis proceeded in three phases: the first two can be characterized as content analysis and coding and the third one as qualitative analysis. In the first phase, we calculated frequencies with which "austerity" as a term was mentioned during the entire timeline, with all the parliamentary plenary sessions as the units of analysis (Portugal $\mathrm{N}=4394$; Spain $\mathrm{N}=2767$ ). This phase was conducted using the keyword search of the term austerity. In the second phase, hits of the term were coded according to policy areas. All the mentions of the term austerity that appear in the different debates or items on the agenda of the plenary sessions were coded, with all the debates that contain at least one mention of the term austerity as the units of analysis (Portugal N=1048, Spain N=801).

\footnotetext{
${ }^{1}$ Although there are different subgenres of parliamentary texts such as ministerial statements, interpellations, parliamentary speeches, questions etc. (see Ilie 2006), this study has analyzed parliamentary debates during plenary sessions in a broad sense, without any particularity on questions, speeches, or interpellations.

${ }^{2}$ This period corresponds to the reestablishment of democracy after the dictatorships. In Spain the new democratic era began in July 1977 after the first general elections for the constituent assembly, whereas in Portugal it was in April 1975.

${ }^{3}$ The parliamentary debates used in this study are available at the Assembly of the Republic (Portugal) and the Congress of Deputies (Spain). See http://debates.parlamento.pt/pesquisa and http://www.congreso.es/portal/page/portal/Congreso/Congreso/Publicaciones/DiaSes/Pleno
} 
This phase was also carried out using the keyword search of the term austerity and by a close reading to identify the topic or content of the debate in which the term is used by MPs. We coded the different parliamentary discussions into 11 policy areas to ensure the inclusion of all the different issues: civic policy; consumption; cultural policy; crime; education; environment; fiscal; foreign and security policy; health; science and technology policy; and social policy. This categorization has been established and used in our research project and in subsequent publications (Alasuutari and VähäSavo 2018; Tiaynen-Qadir, Qadir, and Alasuutari 2018; Rautalin, Alasuutari, and Vento 2019; Alasuutari 2014a, 2014b).

In the third phase, we analyzed the ways in which austerity is evoked by MPs during the whole period in the different policy areas — that is, the arguments and premises put forward when mentioning austerity and the meanings attached to it. In this final phase, we used discourse analysis (Fairclough 2003; Hajer 1995). The interest was not in testing any pre-established categorization, but rather to identify different categories that can be inductively distinguished in the discourses and that include the different ways of invoking austerity. Following another principle in qualitative research, the aim was to create a categorization that applies to all ways of invoking austerity (Alasuutari, Bickman, and Brannen 2008), but without being mutually exclusive. To study whether and how the usages of, and discourses on, austerity have changed over time, we selected a sample to be analyzed discursively. We applied the principle of theoretical sampling (Gobo 2008), which means that the data analyzed contains examples of all different ways and contexts in which austerity is used in the parliamentary debates in these two countries. By applying stratified random sampling, we picked the samples so that they are spread as evenly as possible across different policy areas and years (Portugal $\mathrm{N}=209$; Spain $\mathrm{N}=160$ ).

\section{The Rise and Spread of Austerity in National Policy Making}

Although the term austerity has been used throughout the whole inspected period, it was after 2008 that its usage has increased considerably, coinciding with the economic crisis. As Figure 1 
shows, in 2012 austerity was mentioned in 100 plenary sessions (85 percent) in Portugal and 65 in Spain (84 percent), whereas in 1999 and 2000 it was never mentioned in the Portuguese parliament and only in 15 (21 percent) and 12 (24 percent) sessions in the Spanish parliament in the respective years. Moreover, note that before 2008 the varying frequencies with which austerity was mentioned in these countries differ from each other. In the Portuguese parliament the term was more present in the first years of the reestablishment of democracy. In the Spanish parliament it was used more frequently in the early 1990s. The situation changed after 2008 when, in both parliaments, MPs started invoking the term more or less with the same frequency, showing parallel patterns.

\section{Figure 1. Proportion of Parliamentary Plenary Sessions in Portugal and Spain Including the Term "Austerity"}

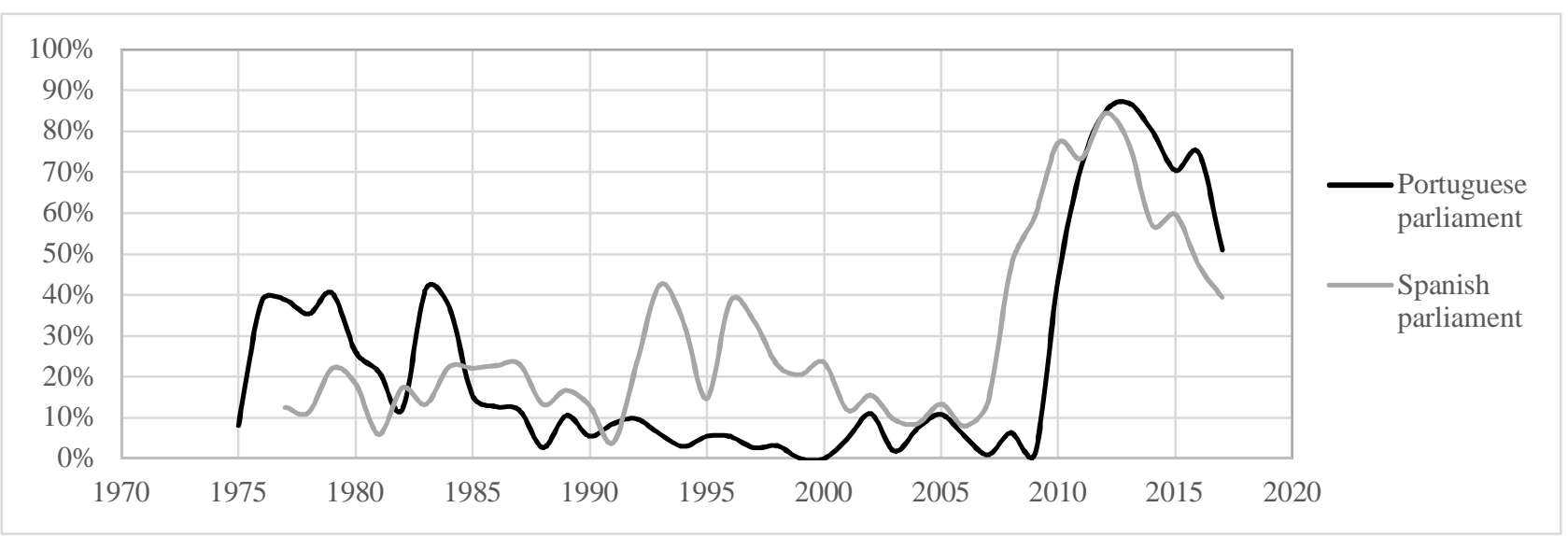

As some scholars point out, applying austerity has always been an issue when tackling economic problems (Blyth 2013a; Clarke and Newman 2012). Indeed, there is a negative correlation with the percentage of annual GDP growth ${ }^{4}$ and the percentage of the appearance of the term austerity in the plenary sessions. The correlation is quite strong in the case of Spain $(-0.627, \mathrm{p}$ significant at the 0.01 level), whereas in the case of Portugal it is considerably lower $(-0,278, \mathrm{p}$ significant at the

\footnotetext{
${ }^{4}$ The data of the GDP growth (annual \%) has been obtained through the database of World Bank at https://data.worldbank.org/indicator/NY.GDP.MKTP.KD.ZG?locations=PT-ES
} 
0.01 level). Hence, it is obvious that the term has become the "bread and butter" of MPs during an economic crisis.

Our analysis of the Portuguese and Spanish cases documents that austerity became a global catchword after the 2008 economic crisis. Although the crisis hit these two countries in somewhat different ways and with a different timing, the patterns in the increased frequency with which MPs started mentioning the term austerity are very similar. This implies that the explanation can be found in the global spread of the discourse, not in the situations at hand in these countries at different moments in time.

To explain why it became possible and feasible for political actors to use the term austerity more frequently, we have identified and coded the policy area of each debate in which austerity is mentioned. As Figure 2 shows, austerity was a term mainly used in fiscal policy before the economic crisis. However, this pattern changed in 2008 when the exclusivity of this term in fiscal policy decreased, and consequently, austerity began to be employed increasingly in other policy areas. For instance, in 1985 of all the mentions of austerity, 73 percent were in fiscal policy in Portugal, and 58 percent in Spain. In 2008 fiscal policy comprised only 14 percent of the mentions in the Portuguese parliament and social policy and education 29 percent each. Similarly, in 2016, fiscal policy comprised only 17 percent of the mentions in the Spanish parliament and social and civic policy comprised 39 percent each. Therefore, we can say that the increased popularity of "austerity" was made possible by the fact that it spread from its original, restricted use in fiscal policy to other policy areas where it was earlier rarely invoked. 
Figure 2. Mentions of "Austerity" in Parliamentary Debates in Portugal and Spain before and after the Crisis by Policy Areas

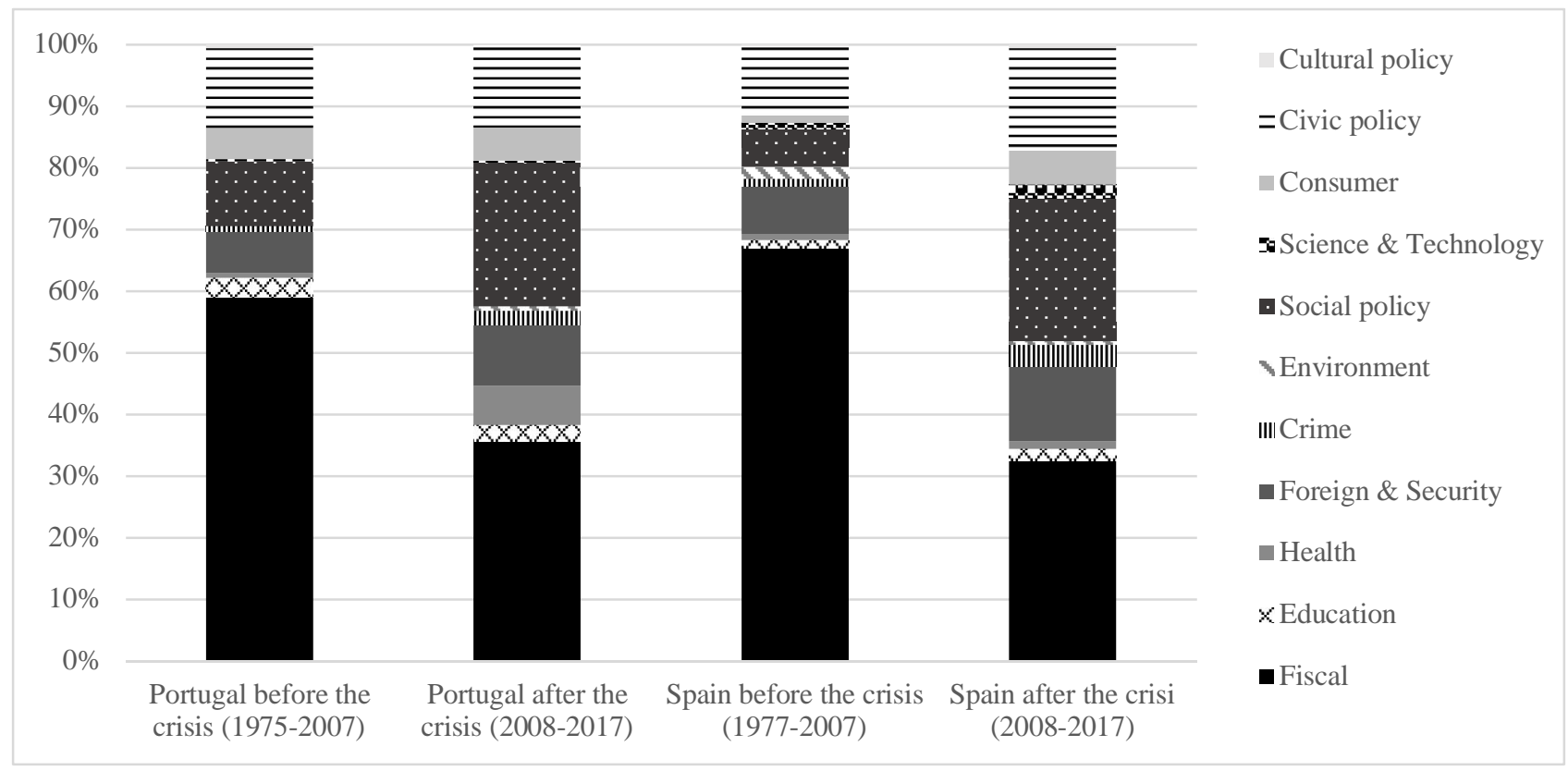

\section{Three Discourses on Austerity}

How was it possible that speakers started to use the word austerity more frequently and in connection to other than just fiscal policy debates? Did the term acquire new meanings? To address these questions, in this section we analyze and compare how "austerity" has been employed before and after 2008. Of all the different mentions during this long period, we can identify three different discourses in which "austerity" is used differently or has a distinct connotation: functionality discourse, fairness discourse, and ideological discourse.

\section{Functionality Discourse}

Before 2008, when "austerity" was not so commonly used, most of the talk about it was in this very functional framework. In this type of discourse, austerity is evoked as a concrete plan of action to return to a certain economic stability. It is presented as a functional idea in which the primary intention is to reduce expenditures in order to be competitive and efficient. Within this discourse, 
austerity can also be understood as a demanding course of action that required a collective effort. Actors might show that nobody wants to apply austerity, but that it is necessary in some situations. In the statement below from Portugal in 2004, we can see how the speaker shows the evidence of its unpopularity, acknowledging the sacrifice that it represents. Austerity is here constructed as a necessary evil.

After two years of great austerity and sacrifice, and even with the continuation of rigour on the expenses, there will be room to increase wages by more than about $2 \%$, this is above the forecast inflation. (Parliament of Portugal 2004, 1006)

This notion of austerity as a functional solution is the prevalent discourse during the whole period. However, from 2008 onward, some actors start being critical of, or at least hesitant with, austerity as a working policy. MPs argue that austerity has the contrary effect to that which it is supposed to redeem: balance, growth, recovery, efficiency, competitiveness, etc. In some cases, speakers refer to certain arguments from abroad to illustrate and reinforce their idea, for instance by pointing out what some international organizations or scientists have said about austerity. We can see an example of this in the quote below from Spain in 2012:

Fortunately, it is no longer just Paul Krugman or other Keynesian economists who tell us about the madness of European austerity. Two weeks ago the International Monetary Fund pointed out to us that budgetary austerity as the only economic policy is counterproductive, that the rapid reduction of the public deficit is having clear contractionary effects on economic growth and employment. (Parliament of Spain 2012, 57)

If austerity was earlier discussed at a more general level, where there was more consensus on its applicability and functionality, later austerity became a central topic discussed and observed in minute detail, generating a variety of opinions on it.

\section{Fairness Discourse}

In addition to the functionality discourse, "austerity" is also invoked to discuss and justify how it should be applied. This discourse was present during the whole period studied. In this discourse, 
austerity is debated in moral terms. The actors emphasize the importance of applying austerity correctly to ensure equality and good functioning of the state in a general sense. We name this talk fairness discourse. Within this discourse, speakers also debate what policies austerity should be applied to, so as to be as harmless as possible. In addition, actors normally justify that citizens and families should not be the main targets experiencing the drawbacks of austerity. For instance, we can find statements where speakers stress that the elites should be the main target of austerity measures. One example of this talk comes from Spain during the 1980s.

Maybe that is not timely at this moment when we have to tighten our belt, we have to implement a policy of austerity, a policy of saving spending. Thus, we have to start setting an example as social leaders, deputies...but not only the political leaders, also the military sector should set an example. (Parliament of Spain 1980, 8561)

However, from 2008 onward, there are also some hesitations on whether there is a reasonable and proper application of austerity policies. For instance, a quote from Portugal in 2013 shows that the effects of austerity always go to the same people: the middle and lower class, the workers, and the families, etc.

Regarding the austerity measures of your Government, Prime Minister, there are no longer two opinions: they are unjust measures that go to the same people as always, on the workers, on the retirees, on the most disadvantaged social groups. (Parliament of Portugal 2013b, 35)

As was the case with the functionality discourses, the fairness of austerity casts some doubts, generating criticisms on, and disputes in, politics after 2008.

\section{Ideological Discourse}

Finally, from 2008 onward, austerity is deemed as an ideology and starts to be understood as a way to act and frame political programs. In this discourse, austerity is not justified as a recipe to tackle some temporary economic problems. Rather, it is framed as a modus operandi, as something that goes beyond its economic connotations. Within this discourse, austerity is regarded as a large political 
program, the objective of which is not only or primarily to balance the budget, but to change the whole system and its power relations. We call this the ideological discourse.

In the name of the crisis, what you did was to apply your ideology, the austerity, the most masochistic austerity, an austerity disguised as cuts and more cuts and, above all, the alarming request of efforts and overexertion to ordinary citizens. (Parliament of Spain 2017, 12)

As we can see here, austerity is articulated as something more than a mere economic intervention. For instance, speakers link austerity to neoliberalism, and call it a philosophy or ideology. In this way they claim that the true goal of those behind austerity measures is to change the current constellation of power, and hence to steer society. Within this discourse, the government is constructed in a new way. It is, for instance, depicted as composed of immoral individuals who just seek their own economic or ideological interest. In some other cases, they are presented as puppets who cannot act by themselves. Such puppets are described as individuals for whom austerity is a dogma that they blindly follow, or a mantra that they repeat without much consideration about what they are actually doing and on the impact that it can have, as in this excerpt from Portugal in 2013.

What the Greens intended with this call was to show to the government that there is a world beyond austerity. They cling to the dogma of austerity and the dictates of the IMF as if it were orders; they remain willing to follow the instructions from abroad religiously. (Parliament of Portugal 2013a, 33)

To conclude, a close reading of parliamentary debates in these two countries shows that, despite some differences concerning the bailout, the discourses within which austerity is discussed are the same. Moreover, the increased frequency of the term coincides with new ways of using it in political talk.

\section{The Domestication of Austerity into Different Policy Areas}

What happens when there are new ways of using the term austerity? Does it somehow affect the fact that it is commonly used in different policy areas and by different political parties? In this section we analyze and explain how the term was used in different issue areas and by different political parties. As pointed out before, austerity has been a term mainly used in fiscal policy. When speakers talked 
about austerity in fiscal policy debates, they used it in a very functional way: it was presented as a very concrete and strategic action that even if it is not pleasant, it is a requirement for the economy.

Yet the hegemony of the functional discourse starts to crumble when "austerity" becomes prevalent in national policy making. The term began to be used more frequently in other political discussions. One reason that we identify here is that the impacts of austerity as such appear in many political spheres, not only on the fiscal one. Therefore, speakers evoke austerity to criticize cuts in the state budget that have important drawbacks in other policy areas, such as social policy, health, education, etc. Speakers start using the term when accusing people of a certain ruling style, and in that way it gets to be used in several other contexts than just when discussing fiscal policy.

When constructed as a whole political and ideological program with other motives than just balancing the state budget, austerity becomes used as a pejorative word. Here austerity becomes an abstract idea, something that can be interpreted in different ways and evoked to apply to many types of political programs. Hence, austerity is shaped as an "umbrella concept," as a term that can describe and fit many political arguments. Any decision or proposal to save or cut state spending can be framed within a larger project of austerity, which is why the number of potential contexts in which it can be used grows substantially. This also means that austerity is not only evoked by members of the cabinet, but also by the opposition. Indeed, at this point the critical views of austerity measures account for the majority of the mentions of the term. Austerity became an assault weapon to criticize its functionality and morality, and to depict the government as unscrupulous people or sheep without any decision-making power.

Traditionally it has been claimed that austerity, with its neoliberal roots, was an idea predominant within the right-wing parties. In this respect, it is interesting to observe who was in the government during the maximum pick of invocations of "austerity," that is, in 2013 in Portugal and in 2012 in Spain (see Figure 1). Certainly, in both cases right-wing parties formed the government (the Partido Popular in Spain, and the Partido Social Democrata and the Centro Democrático Social- 
Partido Popular in Portugal). However, it is even more curious to note that the explosion of the term austerity in parliamentary debates in Spain (2008) and in Portugal (2009) (see Figure 1) was at the time when in both countries left-wing parties formed the government (the Partido Socialista Obrero Español in Spain, and the Partido Socialista in Portugal). Therefore, the increase in the use of the term occurs irrespective of which government is in office. But why is this so? If we pay attention to the ideology of the MPs invoking the term austerity we can detect similarities: all invoke austerity as a shared effort, sacrifice, rigor, and responsibility. Discourses, of course, are adapted to suit the "mood of the time" or circumstances; thus, austerity is perceived as part of common sense. Yet when we observe what type of sacrifices or efforts they mean, there is variation among political ideologies. For instance, right-wing governments tend to focus the austerity on cuts in state spending, whereas the left-wing governments are inclined to raise taxes, especially on big companies and the business sector. In that sense, the abstractness of austerity as a term that encompasses different strategies and interpretations allows for it to be part of different discourses, strategies, and policy areas. Hence, the term austerity was also incorporated throughout the political and ideological spectrum to push for everyone's own austerity ideas or, as we mentioned before, to criticize the austerity ideas of the others.

Indeed, when new ways of talking about austerity emerge and become prevalent, it became easier to use the term in all policy areas. The same happens when it comes to austerity as an abstract term, or something else that its pure functionality and economic connotation; everyone can create their own "austerity," their way to understand, invoke, and apply it. Following the argument of Schmidt and Thatcher (2013), austerity is powerful not because is a defined policy prescription, but because it is part of political rhetoric. Therefore, framing political disputes and choices in terms of the ideological discourse of austerity turned into a routine thing in political talk, which explains the constant battle of this term in many types of political debates. 


\section{Discussion and Conclusions}

In this article we shed light on how ideas spread by studying the case of the term "austerity" as an example of global catchwords. To do that, we examined how this term has been used in Portuguese and Spanish parliamentary discussions from the 1970s until recent years. Empirically, we show that, in national policy making in these countries, the term austerity was present throughout the whole period in both countries with varying intensity. However, its use has increased in recent years. Even though these two countries had different trajectories regarding an international intervention and bailout of state debt, the patterns regarding the frequency with which the term was evoked in these countries are quite similar. The turning point was the year 2008: hits of "austerity" in parliamentary talk increased significantly after that year. Furthermore, before 2008 the term was mainly used in fiscal policy, after which it began to be employed in other policy areas.

From a discursive perspective, we discovered that there was also a shift on how austerity as a term was used after 2008, with no remarkable difference between the two parliaments. Before that year austerity was principally referred to as a necessary means to achieve a balance in the state budget, and the discussion dealt with how austerity measures should be implemented. After 2008, such necessity is challenged and new ways of invoking the term appeared in the debates. On the one hand, MPs evoked austerity to question its functionality; and on the other hand, they articulated it as an ideology. Consequently, the term spread beyond its origins in economic policy discussions. Furthermore, the term, framed within "ideology discourse," was also increasingly invoked by critics of austerity measures, which contributed to its increased use in political talk. This shift did not mean that the older "functionality discourse" disappeared; it coexisted with the new "ideology discourse." Therefore, we conclude that the increased popularity of the term can be explained by its new framings, which made it usable in new contexts.

The finding that the new framings of austerity, enabling a simultaneous explosion of its use in parliamentary debates in Portugal and Spain supports the conclusion that austerity became a 
globally fashionable framing term within which to conceive of, manage, and argue about the 2008 financial crisis. The developed world seemed to face "the age of austerity" (see e.g., Edsall 2012; Schoenbaum 2012; Ortiz and Cummins 2013): the catchword was promoted globally as a remedy and adopted nationally as a "magical" solution (see also Clarke and Newman 2012; DellepianeAvellaneda 2015).

It is important to note that although a fiscal crisis materialized in Portugal and Spain at different moments, the curves that indicate the frequency with which the term austerity was mentioned in these two countries are practically identical. This finding puts into doubt the alternative hypothesis that the adoption of an idea or policy model depends on the circumstances in the recipient country. One can of course argue that the 2008 financial crisis began in the United States and became immediately a global phenomenon that affected the entire world. Yet we can separate out global awareness of events that may have local repercussions from policies proposed for dealing with the potential consequences in national contexts.

We acknowledge that our study has limitations in terms of its scope as it concentrates only on the study of the term austerity. In that sense, some related terms and expressions such as reduction and cutbacks also shaped the discourses and measures on austerity although they were not directly addressed in our study. Moreover, our analysis is limited to two case studies. In this respect, further research could be conducted to see, for instance, whether the increased use of "austerity" started simultaneously and followed the same pattern in other countries. Finally, we do not think that our study provides an exhaustive list of reasons for the increased popularity of austerity. Rather, we acknowledge that there can be other mechanisms that explain how austerity has become a catchword. Previous research shows that international governmental and non-governmental organizations play an important role in advocating and spreading new ideas and discourses (Frank, Hironaka, and Schofer 2000; Alasuutari 2016). Hence, it would be interesting to study how international organizations such as the IMF, the World Bank, the EU, and the Organization for Economic Co- 
operation and Development have contributed to spreading and shaping national discourses and policies on austerity.

\section{About the Authors}

Laia Pi Ferrer is a doctoral student in Social Sciences (Sociology) at Tampere University, Faculty of Social Sciences. She is interested in globalization and transnational sociology, and how power and politics are approached from cultural and new institutionalist perspectives. Her doctoral research studies how the national policies in Portugal and Spain were re-thought and discussed during the period of the recent economic crisis (2008-13). In addition, she seeks to determine whether and how these new policies and reforms are synchronized with each other, and to discover whether and how the international community plays an important role in them.

Pertti Alasuutari, PhD, is Academy Professor at Tampere University, Faculty of Social Sciences. His research interests include global and transnational phenomena, media, social theory, and social research methodology. His monographs include The Synchronization of National Policies (Routledge 2016), Social Theory and Human Reality (Sage 2004), Rethinking the Media Audience (Sage 1999), An Invitation to Social Research (Sage 1998), and Researching Culture: Qualitative Method and Cultural Studies (Sage 1995). He has a total of 176 scientific publications, including 46 peer-reviewed articles and nine books in English.

\section{References}

Afonso, Alexandre, Sotirios Zartaloudis, and Yannis Papadopoulos. 2015. "How Party Linkages Shape Austerity Politics: Clientelism and Fiscal Adjustment in Greece and Portugal During the Eurozone Crisis." Journal of European Public Policy 22 (3): 315-334. Accessed on June 17, 2019. Available online at https://doi.org/10.1080/13501763.2014.964644

Alasuutari, Pertti. 2016. The Synchronization of National Policies: Ethnography of the Global Tribe of Moderns. London: Routledge.

2014a. "Following the Example of Other Countries? Policy Analysis of New Legislation in Canada, the United Kingdom and the United States." Journal of Comparative Policy Analysis: Research and Practice 16 (3): 266-279. Accessed on June 17, 2019. Available online at https://doi.org/10.1080/13876988.2013.870116

. 2014b. "Interdependent Decision-Making in Practice: Justification of New Legislation in Six Nation States." In National Policy-Making: Domestication of Global Trends edited by Pertti Alasuutari and Ali Qadir. London: Routledge. 25-43 
Alasuutari, Pertti, Leonard Bickman, and Julia Brannen. (Eds.) 2008. The SAGE Handbook Of Social Research Methods. Thousand Oaks, CA: Sage.

Alasuutari, Pertti, and Ali Quadir. (Eds.). 2014. National Policy-Making: Domestication Of Global Trends. London: Routledge.

Alasuutari, Pertti, and Valtteri Vaha-Savo. 2018. "Owning Worldwide Principles: The Case of American Exceptionalism." Social Science Information 57 (4): 533-552. Accessed on June 17, 2019. Available online at https://doi.org/10.1177/0539018418816192

Alesina, Alberto, Silvia Ardagna, Roberto Perotti, and Fabio Schiantarelli. 2002. "Fiscal Policy, Profits, And Investment." The American Economic Review 92 (3): 571-589. Accessed on June 17, 2019. Available online at https://www.aeaweb.org/articles?id=10.1257/00028280260136255

Alesina, Alberto, and Roberto Perotti. 1997. "Fiscal Adjustments in OECD Countries: Composition and Macroeconomic Effects." International Monetary Fund Staff Papers 44 (2): 210-248. Accessed on June 17, 2019. Available online at https://link.springer.com/article/10.2307/3867543

Alesina, Alberto, and Howard Rosenthal. 1995. Partisan Politics, Divided Government, and The Economy. Cambridge: Cambridge University Press.

Anderson, Barry, and Elizabeth Minneman. 2014. "The Abuse and Misuse of the Term "Austerity": Implications for OECD Countries." OECD Journal on Budgeting 14 (1): 109-122. Accessed on June 17, 2019. Available online at https://doi.org/10.1787/16812336

Andrade, João. S., And Adelaide Duarte. 2011. "The Fundamentals of the Portuguese Crisis." Panoeconomicus 58 (2): 195-218. Accessed on June 17, 2019. Available online at http://scindeks.ceon.rs/article.aspx?artid=1452-595X1102195A

Anstead, Nick. 2017. "The Idea of Austerity in British Politics, 2003-2013." Political Studies 66 (2): 287-305. Accessed on June 17, 2019. Available online at https://doi.org/10.1177/0032321717720376

Baker, Andrew, and Geoffrey Rd. Underhill. 2015. "Economic Ideas and the Political Construction of the Financial Crash of 2008." The British Journal of Politics and International Relations 17 (3): 381390. Accessed on June 17, 2019. Available online at https://doi.org/10.1111/1467-856X.12072

Béland, Daniel. 2005. "Ideas and Social Policy: An Institutionalist Perspective." Social Policy \& Administration 39 (1): 1-18. Accessed on June 17, 2019. Available online at https://onlinelibrary.wiley.com/doi/full/10.1111/j.1467-9515.2005.00421.x

. 2009. "Ideas, Institutions, and Policy Change." Journal of European Public Policy 16 (5): 701-718. Accessed on June 17, 2019. Available online at https://doi.org/10.1080/13501760902983382

Béland, Daniel, and Robert Henry Cox. 2016. "Ideas as Coalition Magnets: Coalition Building, Policy Entrepreneurs, and Power Relations." Journal of European Public Policy 23 (3): 428-445. Accessed on June 17, 2019. Available online at https://doi.org/10.1080/13501760902983382

Blyth, Mark. 2013a. Austerity: The History of a Dangerous Idea. Oxford: Oxford University Press.

. 2013b. "Paradigms and Paradox: The Politics of Economic Ideas in Two Moments of Crisis."

Governance 26 (2): 197-215. Accessed on June 17, 2019. Available online athttps://onlinelibrary.wiley.com/doi/full/10.1111/gove.12010

Boix, Carles. 2000. "Partisan Governments, the International Economy, and Macroeconomic Policies in Advanced Nations, 1960-93." World Politics 53 (1): 38-73. Accessed on June 17, 2019. Available online at https://doi.org/10.1017/S0043887100009370

Bramall, Rebecca.2013. The Cultural Politics of Austerity: Past and Present in Austere Times. New York, NY: Palgrave Macmillan. 
Carstensen, Martin B. 2015. "Conceptualising Ideational Novelty: A Relational Approach." The British Journal of Politics \& International Relations 17 (2): 284-297. Accessed on June 17, 2019. Available online at https://doi.org/10.1111/1467-856X.12030

2011a. "Ideas Are Not as Stable as Political Scientists Want Them to Be: A Theory of Incremental Ideational Change." Political Studies 59 (3): 596-615. Accessed on June 17, 2019. Available online at https://doi.org/10.1111/j.1467-9248.2010.00868.x

2011b. "Paradigm Man vs. the Bricoleur: Bricolage as an Alternative Vision of Agency in Ideational Change." European Political Science Review 3 (1): 147-167. Accessed on June 17, 2019. Available online at https://doi.org/10.1017/S1755773910000342

Chwieroth, Jeffrey M. 2010. "How Do Crises Lead to Change? Liberalizing Capital Controls in the Early Years of New Order Indonesia." World Politics 62 (3): 496-527. Accessed on June 17, 2019. Available online at https://doi.org/10.1017/S0043887110000110

2007. "Testing and Measuring the Role of Ideas: The Case of Neoliberalism in the International Monetary Fund." International Studies Quarterly 51 (1): 5-30. Accessed on June 17, 2019. Available online at https://doi.org/10.1111/j.1468-2478.2007.00437.x

Clarke, John, and Janet Newman. 2012. "The Alchemy of Austerity." Critical Social Policy 32 (3): 299319. Accessed on June 17, 2019. Available online at https://doi.org/10.1177/0261018312444405

Cox, Robert Henry, and Daniel Béland. 2013. "Valence, Policy Ideas, and the Rise of Sustainability." Governance 26 (2): 307-328. Accessed on June 17, 2019. Available online at https://onlinelibrary.wiley.com/doi/full/10.1111/gove.12003

De Rugy, Veronique. 2013. "Is Austerity the Answer to Europe's Crisis?" Cato Journal 33 (2): 245251. Accessed on June 17, 2019. Available online at https://heinonline.org/HOL/LandingPage?handle=hein.journals/catoj33\&div=20\&id=\&page=\&t=1

\section{$\underline{60764211}$}

Della Porta, Donatella, and Alice Mattoni. 2014. "Patterns of Diffusion and the Transnational Dimension of Protest in the Movements of the Crisis: An Introduction." In Spreading Protest. Social Movements in Times of Crisis, edited by Donatella Della Porta and Alice Mattoni. Colchester: ECPR Press. 1-18.

Dellepiane-Avellaneda, Sebastian. 2015. "The Political Power of Economic Ideas: The Case of 'Expansionary Fiscal Contractions'." The British Journal of Politics and International Relations 17 (3): 391-418. Accessed on June 17, 2019. Available online at https://doi.org/10.1111/1467-856X.12038

Edsall, Byrne. 2012. The Age of Austerity. New York, NY: Doubleday.

Fairclough, Norman. 2003. Analysing Discourse: Textual Analysis for Social Research. London: Routledge.

Fontana, Giuseppe, and Malcolm Sawyer. 2011. "Fiscal Austerity: Lessons from Recent Events in the British Isles." Challenge 54 (2): 42-60. Accessed on June 17, 2019. Available online at https://doi.org/10.2753/0577-5132540202

Fran, David John, Ann Hironaka, and Evan Schofer. 2000. "The Nation-State and the Natural Environment over the Twentieth Century." American Sociological Review 65 (1): 96-116. Accessed on June 17 2019. Available online at https://www.jstor.org/stable/2657291?seq=1\#metadata_info_tab_contents

Gobo, Giampietro. 2008. "Re-conceptualising Generalisation: Old Ideas in a New Frame." In The SAGE Handbook of Social Research Methods, edited by Pertti Aluusatari, Leonard Bickman, and Julia Brannen. London: Sage. 193-213. 
Gorjão, Paulo. 2012. "Portugal and the Straitjacket of the European Financial Crisis." The International Spectator 47 (4): 64-68. Accessed on June 17, 2019. Available online at https://doi.org/10.1080/03932729.2012.743644

Guajardo, Jaime, Daniel Leigh, and Andrea Pescatori. 2014. "Expansionary Austerity? International Evidence." Journal of the European Economic Association 12 (4): 949-968. Accessed on June 17, 2019. Available online at https://doi.org/10.1111/jeea.12083

Hafner-Burton, Emilie M., and Kiyoteru Tsutsui. 2005. "Human Rights in a Globalizing World: The Paradox of Empty Promises." The American Journal of Sociology 110 (5): 1373-1411. Accessed on June 17, 2019. Available online at https://www.journals.uchicago.edu/doi/abs/10.1086/428442

Hafner-Burton, Emilie M., Kiyoteru Tsutsui, and John W. Meyer. 2008. "International Human Rights Law and the Politics of Legitimation: Repressive States and Human Rights Treaties." International Sociology 23 (1): 115-141. Accessed on June 17, 2019. Available online at https://doi.org/10.1177/0268580907084388

Hajer, Maarten A. 1995. The Politics of Environmental Discourse: Ecological Modernization and the Policy Process. Oxford: Oxford University Press.

Helgadóttir, Oddný. 2016. "The Bocconi Boys go to Brussels: Italian Economic Ideas, Professional Networks and European Austerity." Journal of European Public Policy 23 (3): 392-409. Accessed on June 17, 2019. Available online at https://doi.org/10.1080/13501763.2015.1106573

Hofferberth, Matthias. 2015. "Mapping the Meanings of Global Governance: A Conceptual Reconstruction of a Floating Signifier." Millennium 43 (2): 598-617. Accessed on June 17, 2019. Available online at https://doi.org/10.1177/0305829814561539

Ilie, Cornelia. 2006. "Parliamentary Discourses." In Encyclopedia of Language and Linguistics, edited by Keith Brown. Oxford: Elsevier. 188-197.

Jabko, Nicolas. 2013. "The Political Appeal of Austerity." Comparative European Politics 11 (6): 705-712. Accessed on June 17, 2019. Available online at https://link.springer.com/article/10.1057/cep.2013.21

2006. Playing the Market: A Political Strategy for Uniting Europe, 1985-2005. New York, NY: Cornell University Press.

Jacobs, Alan M. 2009. "How Do Ideas Matter? Mental Models and Attention in German Pension Politics." Comparative Political Studies 42 (2): 252-279. Accessed on June 17, 2019. Available online at https://doi.org/10.1177/0010414008325283

Jenson, Jane. 2010. "Diffusing Ideas for after Neoliberalism: The Social Investment Perspective in Europe and Latin America." Global Social Policy 10 (1): 59-84. Accessed on June 17, 2019 Available online at https://doi.org/10.1177/1468018109354813

Kingdon, John W. 2003. Agendas, Alternatives, and Public Policies. 2d ed. New York, London: Longman 1993. "How Do Issues Get on the Public Policy Agenda?" In Sociology and the Public Agenda, edited by William J Wilson. Newbury Park, CA: Sage. 40-50.

1984. Agendas, Alternatives and Public Policies. New York, NY: Longman.

Kriesi, Hanspeter. 2002. "The Political Consequences of the Financial and Economic crisis in Europe: Electoral Punishment and Popular Protest." Swiss Political Science Review 18 (4): 518-522. Accessed on June 17, 2019. Available online at https://onlinelibrary.wiley.com/doi/full/10.1111/spsr.12006

Laclau, Ernesto, and Chantal Mouffe. 1985. Hegemony and Socialist Strategy: Toward a Radical Democratic Politics. New York, NY: Verso. 
Lallement, Michel. 2011. "Europe and the Economic Crisis: Forms of Labour Market Adjustment and Varieties of Capitalism." Work, Employment and Society 25 (4): 627-641. Accessed on June 17, 2019. Available online at https://doi.org/10.1177/0950017011419717

Lanchester, John. 2013. "Let's Call It Failure." London Review of Books 35 (1): 3-6. Accessed on June 17, 2019. Available online at https://www.lrb.co.uk/v35/n01/john-lanchester/lets

call-it-failure

Levi-Strauss, Claude. 1962. The Savage Mind. Oxford: Oxford University Press.

McBride, Stephen. 2014. "In Austerity We tTust." In Orchestrating Austerity: Impacts and Resistance, edited by Donna Baines and Stephen McBride. Halifax, NS: Fernwood Publishing. 10-18.

Merriam-Webster. 2010. ""Word of the Year 2010". Accessed on June 17, 2019. Available online at https://www.merriam-webster.com/words-at-play/2014-word-of-the-year-retrospective/2010-austerity

Meyer, John W. 2004. "The Nation as Babbitt: How Countries Conform." Contexts 3 (3): 42-47. Accessed on June 17, 2019. Available online at https://doi.org/10.1525/ctx.2004.3.3.42

Moury, Catherine, and Adam Standring. 2017. "'Going beyond the troika': Power and Discourse in Portuguese Austerity Politics." European Journal of Political Research 56 (3) :660-679. Accessed on June 17, 2019. Available online at https://ejpr.onlinelibrary.wiley.com/doi/full/10.1111/1475$\underline{6765.12190}$

Mulas-Granados, Carlos. 2003. "The Political and Economic Determinants of Budgetary Consolidation in Europe." European Political Economy Review 1 (1): 015-039. Accessed on June 17, 2019. Available online at http://aei.pitt.edu/631/

Obinger, Herbert, and Uwe Wagschal. 2001. "Families of Nations and Public Policy." West European Politics 24 (1): 99-114. Accessed on June 17, 2019. Available online at https://doi.org/10.1080/01402380108425419

Ortiz, Isabel, and Matthew Cummins. 2013. The Age of Austerity: A Review of Public Expenditures and Adjustment Measures in 181 Countries. New York, NY: Initiative for Policy Dialogue. Accessed on June 17, 2019. Available online at http://dx.doi.org/10.2139/ssrn.2260771

Panitch, Leo, and Sam Gindin. 2009. "Forum the Current Crisis: A Socialist Perspective." Studies in Political Economy 83 (1): 7-31. Accessed on June 17, 2019. Available online at https://doi.org/10.1080/19187033.2009.11675054

Parliament of Portugal. 2013a. "On Social Functions of the State (in Opening the Debate on the nterpellation)." Assembly of the Republic. February 21. Accessed on June 17, 2019. Available online at http://debates.parlamento.pt/catalogo/r3/dar/01/12/02/057/2013-02-21?sft=true \&q=austeridade $\&$ from=2013$\underline{02-20 \& \text { to }=2013-02-24 \# \mathrm{p} 3}$

. 2013b. "Law of Follow-up, Appreciation and Pronunciation by the Assembly of the Republic in the Framework of the Process of Construction of the European Union.” Assembly of the Republic. June 26. Accessed on June 17, 2019 . Available online at http://debates.parlamento.pt/catalogo/r3/dar/01/12/02/105/2013-06-26? $\mathrm{ft}=$ true \&q=austeridade $\&$ from=201306-26\& to=2013-06-27\#p8

2004. "Law Proposals no. 145 / IX - Major Plan Options for 2005 and 146 / IX - State Budget for 2005." Assembly of the Republic. November 18. Accessed on June 17, 2019. Available online at http://debates.parlamento.pt/catalogo/r3/dar/01/09/03/018/2004-11-

$18 ? \mathrm{sft}=$ true $\& \mathrm{q}=$ austeridade $\&$ from $=2004-11-18 \&$ to $=2004-11-19 \# \mathrm{p} 1006$

Parliament of Spain. 2017. "Royal Decree-law 6/2017, of March 31, Approving the Offer of Public Employment in the Fields of Non-university and University Teaching Staff, Armed Forces, State Security Forces and Corps and Police Bodies Dependent on the Autonomous Communities for 2017." 
Congress of Deputies. May 11. Accessed on June 17, 2019. Available online at http://www.congreso.es/public oficiales/L12/CONG/DS/PL/DSCD-12-PL-52.PDF

2012. "Bill of General State Budgets for the Year 2013." Congress of Deputies. October 23. Accessed on June 17, 2019. Available online at http://www.congreso.es/public_oficiales/L10/CONG/DS/PL/DSCD-10PL-67.PDF

. 1980. "Bill of General State Budgets for the Year 1981 (continuation)." Congress of Deputies. December 2. Accessed on June 17, 2019. Available online at http://www.congreso.es/public oficiales/L1/CONG/DS/PL/PL 134.PDF

Petry, Johannes. 2013. "From PIIGS and the Drive towards Austerity: The Discursive Construction of the Eurozone Crisis and its Impact on European Welfare States." Paper presented at the DVPW, ÖGPW, SVPW Joint Conference "Drei-Länder-Tagung: Politik der Vielfalt." September 19-21. University of Innsbruck, Austria. Accessed on June 17, 2019. Available online at https://papers.ssrn.com/sol3/papers.cfm?abstract_id=2329304

Potts, Shaina, and Sergio Montero. 2010. "Restraints on European Recovery: Structural and Ideological Impediments to Reviving Greece and the Eurozone after the Crisis." Berkeley Planning Journal 23 (1): 178-182. Accessed on June 17, 2019. Available online at https://doi.org/10.5070/BP323111437

Qadir, Ali, and Pertti Alasuutari. 2013. "Taming Terror: Domestication of the War on Terror in the Pakistan Media." Asian Journal of Comminication 23 (6): 575-589. Accessed on June 17, 2019. Available online at https://doi.org/10.1080/01292986.2013.764905

Queirós, António J. 2009. "As relações luso-espanholas: do final da Primeira República à Revolução dos Cravos (1926-1974) [The Lusitanian-Spaniard relation: from the end of the First Republic to the Carnation Revolution (1926-1974)]." Agália: Publicação internacional da Associação Galega da Língua 97: 199-208. Accessed on June 17, 2019. Available online at https://dialnet.unirioja.es/servlet/articulo?codigo=3966013

Rautalin, Marjaana, Pertti Alasuutari, and Eetu Vento. 2019. "Globalisation of Education Policies: Does PISA Have an Effect?" Journal of Education Policy 34 (4): 500-522. Accessed on June 17, 2019. Available online at https://doi.org/10.1080/02680939.2018.1462890

Risse-Kappen, Thomas. 1994. "Ideas Do Not Float Freely: Transnational Coalitions, Domestic Structures, and the End of the Cold War." International organization 48 (2): 185-214. Accessed on June 17, 2019. Available online at https://doi.org/10.1017/S0020818300028162

Royo, Sebastián. 2013. "How Did the Spanish Financial System Survive the First Stage of the Global Crisis?" Governance 26 (4): 631-656. Accessed on June 17, 2019. Available online at https://onlinelibrary.wiley.com/doi/full/10.1111/gove.12000

Salomon, Margot E. 2015. "Of Austerity, Human Rights and International Institutions." European Law Journal 21 (4): 521-545. Accessed on June 17, 2019. Available online at https://onlinelibrary.wiley.com/doi/full/10.1111/eulj.12138

Sardica, José M. 2014. "The Cultural Discourse of Contemporary Portuguese Iberianism." International Journal of Iberian Studies 27 (1): 55-70. Accessed on June 17, 2019. Available online at https://doi.org/10.1386/ijis.27.1.55 1

Schmidt, Vivien A. 2015. "Discursive Institutionalism: Understanding Policy in Context." In Handbook of Critical Policy Studies, edited by Daniel Béland and Robert Henry Cox. Oxford: Oxford University Press. 171-189.

2014. "Speaking to the Markets or to the People? A Discursive Institutionalist Analysis of the EU's Sovereign Debt Crisis." The British Journal of Politics and International Relations 16 (1): 188-209. Accessed on June 17, 2019. Available online at https://doi.org/10.1111/1467-856X.12023 
2012. "Discursive Institutionalism: Scope, Dynamics, and Philosophical Underpinnings." In The Argumentative Turn Revisited: Public Policy as Communicative Practice, edited by Frank Fischer and John Forest. Durham, NC: Duke University Press. 85- 113.

2011. "Speaking of Change: Why Discourse Is Key to the Dynamics of Policy Transformation." Critical Policy Studies 5 (2): 106-126. Accessed on June 17, 2019. Available online at https://doi.org/10.1080/19460171.2011.576520

2008. "Discursive Institutionalism: The Explanatory Power of Ideas and Discourse." Political Science 11 (1): 303-326. Accessed on June 17, 2019. Available online at https://doi.org/10.1146/annurev.polisci.11.060606.135342

2001. "The Politics of Economic Adjustment in France and Britain: When Does Discourse Matter?" Journal of European Public Policy 8 (2): 247-264. Accessed on June 17, 2019. Available online at https://doi.org/10.1080/13501760110041578

Schmidt, Vivien A., and Claudio M. Radaelli. 2004. "Policy Change and Discourse in Europe: Conceptual and Methodological Issues." West European Politics 27 (2): 183-210. Accessed on June 17, 2019. Available online at https://doi.org/10.1080/0140238042000214874

Schmidt, Vivien A., and Mark Thatcher. 2013. "Theorizing Ideational Continuity: The Resilience of Neoliberal Ideas in Europe." In Resilient Liberalism in Europe's Political Economy, edited by Vivien A. Schmidt and Mark Thatcher. Cambridge: Cambridge University Press. 1-52.

Schoenbaum, Thomas J. 2012. The Age of Austerity: The Global Financial Crisis and the Return to Economic Growth. Northampton, MA: Edward Elgar.

Shandra, John M. 2007. "The World Polity and Deforestation." International Journal of Comparative Sociology 48 (1): 5-27. Accessed on June 17, 2019. Available online at https://doi.org/10.1177/0020715207072157

Simmons, Beth A., Frank Dobbin, and Geoffrey Garrett. 2008. "Introduction: The Diffusion of Liberalization." In The Global Diffusion of Markets and Democracy, edited by Beth A. Simmons, Frank Dobbin and Geoffrey Garrett. New York: Cambridge University Press. 1-63

Strang, David, and John W. Meyer. 1993. "Institutional Conditions for Diffusion." Theory and Society 22 (4): 487-511. Accessed on June 17, 2019. Available online at https://link.springer.com/article/10.1007\%2FBF00993595?LI=true

Tavares, José. 2004. "Does Right or Left Matter? Cabinets, Credibility and Fiscal Adjustments." Journal of Public Economics 88 (12): 2447-2468. Accessed on June 17, 2019. Available online at https://doi.org/10.1016/j.jpubeco.2003.11.001

Tervonen-Gonçalves, Leena. 2012. "From Averages to Best Performers: Use of Comparisons in Identity Formation." Critical Policy Studies 6 (3): 304-323. Accessed on June 17, 2019. Available online at https://doi.org/10.1080/19460171.2012.717784

Theodoropoulou, Sotiria, and Andrew Watt. 2011. "Withdrawal Symptoms: An Assessment of the Austerity Packages in Europe." European Union Trade Institute, Working Paper no. 2011.02. Accessed on June 17, 2019. Available online at https://papers.ssrn.com/sol3/papers.cfm?abstract id=2221838

Tiaynen-Qadir, Tatiana, Ali Qadir, and Pertti Alasuutari. 2018. "Russia in World Society: A Comparative Perspective on International References in Parliamentary Debates." Acta Sociologica. Accessed on June 17, 2019. Available online at https://doi.org/10.1177/0001699317749287

Walter, Stefanie. 2016. "Crisis Politics in Europe: Why Austerity is Easier to Implement in Some Countries than in Others." Comparative Political Studies 49 (7): 841-873. Accessed on June 17, 2019. Available online at https://doi.org/10.1177/0010414015617967 